\title{
Petroleum Water Contamination Resulting from Change in Land-Use in Paloich, South Sudan: Azolla pinnata and Lemna minor L. as an Efficient Bio Treatment Tool
}

\author{
Emmanuel Tete Ezbon Simon'1, Isa Zaharadden², Abu-Hanifa Babati², Xinrong Zhang1* \\ ${ }^{1}$ College of Earth Science, Jilin University, Changchun, China \\ ${ }^{2}$ Department of Geography, Kaduna State University, Kaduna, Nigeria \\ Email: ^zangxr@jlu.edu.cn
}

How to cite this paper: Simon, E.T.E., Zaharadden, I., Babati, A.-H. and Zhang, X.R. (2021) Petroleum Water Contamination Resulting from Change in Land-Use in Paloich, South Sudan: Azolla pinnata and Lemna minor L. as an Efficient Bio Treatment Tool. Open Journal of Geology, 11, 396-410.

https://doi.org/10.4236/ojg.2021.119022

Received: July 22, 2021

Accepted: September 23, 2021

Published: September 26, 2021

Copyright $\odot 2021$ by author(s) and Scientific Research Publishing Inc. This work is licensed under the Creative Commons Attribution International License (CC BY 4.0).

http://creativecommons.org/licenses/by/4.0/

\begin{abstract}
The study focused on the change in land-use and phytoremediation and biosorption efficacy of Lead and Cadmium from the petroleum-contaminated water by Lemna minor L. and Azolla pinnata. For the study of the change in land-use in Paloich, satellite imagery of Paloich between 2000 and 2020 was obtained from http://www.earthexplore.usgs.org/ and analyses. Water samples were collected at different points of Paloich. Experimental set-up consisted of four main samples sets viz: Lemna minor $L$. and petroleum-contaminated water, Azolla pinnata and petroleum contaminated water, combination of Lemna minor L., Azolla pinnata and petroleum-contaminated water then distilled water (control) all containing 3 liters of the water. Samples were left for 28 days. Physico-chemical parameters, heavy metals ( $\mathrm{Pb}$ and $\mathrm{Cd})$ and biosorption capacity were analyzed. The result indicates the changes in the land-use that occurred in the area of study for a given period (2000-2020). Built-up area, mining site and environmental degradation have increased by 8 percent between the periods. The reason behind the increase can be as a result of increase in population. The result also indicates high efficiency in pollutant reduction in the set-up containing the combination of Lemna minor $L$. and Azolla pinnata in which the $\mathrm{Cd}$ and $\mathrm{Pb}$ reduction efficiency recorded was 95\% and $97 \%$ respectively. While set up containing Azolla $\mathrm{P}$. had $\mathrm{Pb}$ and $\mathrm{Cd}$ reduction efficiency of $83 \%$ and $87 \%$ respectively. However, the set up containing Lemna minor L. has $\mathrm{Pb}$ and Cd reduction efficiency of $91 \%$ and $85 \%$ respectively. A significant absorption of the metals $(\mathrm{Pb}$ and $\mathrm{Cd})$ were seen in the samples with the mixture of Lemna minor L. and Azolla pinnata. As such this study reveals the potentiality of Lemna minor L. and Azolla pinnata as
\end{abstract}


some excellent phytoremediation candidates in the treatment of effluents containing Lead and Cadmium; however, we also recommend further studies on the efficacy of such plants in other classes of heavy metals.

\section{Keywords}

Remediation, Biotechnology, Macrophytes, Climate Change, Pollution

\section{Introduction}

One of the ways of counteracting the effect of an increasing population is exploration and production of oil and gas. Most countries, particularly Africa, depend on this sector for economic stability [1]. The benefits of oil exploration and production include easy extraction, power generation, industrial growth, infrastructural development, and many more. The by-products of petroleum products include fertilizers, pesticides, and insecticides, which are important elements for the enhancement of agricultural products [2]. One of the negative effects associated with oil exploration and production is pollution. During oil exploration, opportunities exist for the release of pollutants such as straight chained, branched, cyclic, monocyclic aromatic, polycyclic aromatic hydrocarbons, and inorganic compounds including heavy metals, sulphide, sulphate, nitrate, phosphate, dissolved solids, suspended solids, etc. [3] [4] [5].

About $40 \%$ of the country's GDP is dependent on oil exports. The continuous prevention of reports on pollution in Paloich is the reason for the scanty literature showing the extent of oil pollution and how it has impacted negatively on the people of the Paloich community [6]. The increasing number of children born with deformations can be linked to the teratogenic effects resulting from exposure to oil pollution [7] [8] [9]. The incessant increase in the rate of deaths of the inhabitants of the Paloich community due to unknown ills could also be attributed to the result of exposure to oil pollutants. The exposure of the inhabitants of the Paloich community is as a result of poor clean-up of oil pollutants in the field. This pollutant causes soil degradation and pollutes water resources. The presence of toxic chemicals in the environment also contributes to air pollution making breathing impossible for the inhabitants of the Paloich community [10] [11] [12].

These pollutants tend to seep into aquifers and pollute underground water, while some proportion of these pollutants tend to move as runoff into nearby surface water where they cause negative effects on the biota [13] [14] [15]. The release of these pollutants into the environment poses a serious threat to aquatic organisms in nearby surface water and also to the human community in proximity to this surface water. This is because the majority of the population in South Sudan depends on underground or stream water for recreational and farming activities [16] [17] [18]. These pollutants can sometimes sink into the ground, leading to the pollution of underground water, thereby posing serious 
toxicity at low level exposure due to the presence of heavy metals which have been associated with chronic and acute toxicological effect on man [19] [20] [21]. Heavy metals have also been shown by many researchers to be detrimental to aquatic organisms, including algae, plants, and other aquatic invertebrate and vertebrate organism [22] [23] [24].

Many physical, chemical and biological methods have been employed to treat this petroleum contaminated water effectively to prevent further degradation of the environment, but most of the technologies are not easily accessible due to cost [25] [26] [27]. It is, therefore, necessary to look for alternative methods to effectively treat petroleum contaminated water, thereby restoring environmental quality. Biosorption and phytoremediation are biological methods that can eradicate the problem associated with petroleum contaminated water, because both processes have been shown by researchers to be effective in the treatment of different wastewater including [28] [29] [30]. The current study aims to determine the effect of the change in land-use in Paloich for petroleum mining activity and to test the role of Azolla pinnata and Lemna minor L. as an Efficient Biotreatment Tool.

\section{Materials and Methods}

\subsection{Study Area}

The Paloich is located at latitude $6.750^{\circ} \mathrm{N}$ and longitude $30.133^{\circ} \mathrm{E}$. The area is characterized by low-lying plains that rise to the highlands in the north. A massive swamp is located in the south and is fed by the White Nile (Figure 1). This area has been further characterized as being covered with "Acacia seyal Balanites Savannah, alternating with grass areas. Different types of low and high rainfall savannah cover a substantial part of the area. The climate is characterized by seasonal rainfall and hot temperatures [31]. During the rainy season, which lasts from June to October, the area gets swampy. November to May constitutes the dry season. The climate is hot, with annual mean temperatures between $26^{\circ}$ and $28^{\circ}$ Celsius. Annual mean rainfall ranges between 600 and $800 \mathrm{~mm}$ [32].

Satellite imagery was obtained from www.earthexplore.usgs.org. This includes Landsat (ETM-2000, and OLS-2020). These will be chosen because they provide just the necessary details required and at no cost. Supervised classification was used by a careful training sample was selected using Google earth imageries. The cluster pixels in a data set into classes corresponding to user-defined regions of interest (ROIs) or training classes which are selected as representative areas to be mapped in the output. Maximum Likelihood techniques were used to classify the images. Therefore, six classes were developed. These are built up areas (residential areas, transportation structures, and other erected buildings for domestication), water bodies (rivers, streams, artificial and natural dams, ditches, and any place that holds water during the study), sparse vegetation (farm land, shrubs, grass land, and any area with sparse vegetation), dense vegetation (riparian vegetation, and forested areas), bare surfaces (such as exposed surfaces and dunes), 


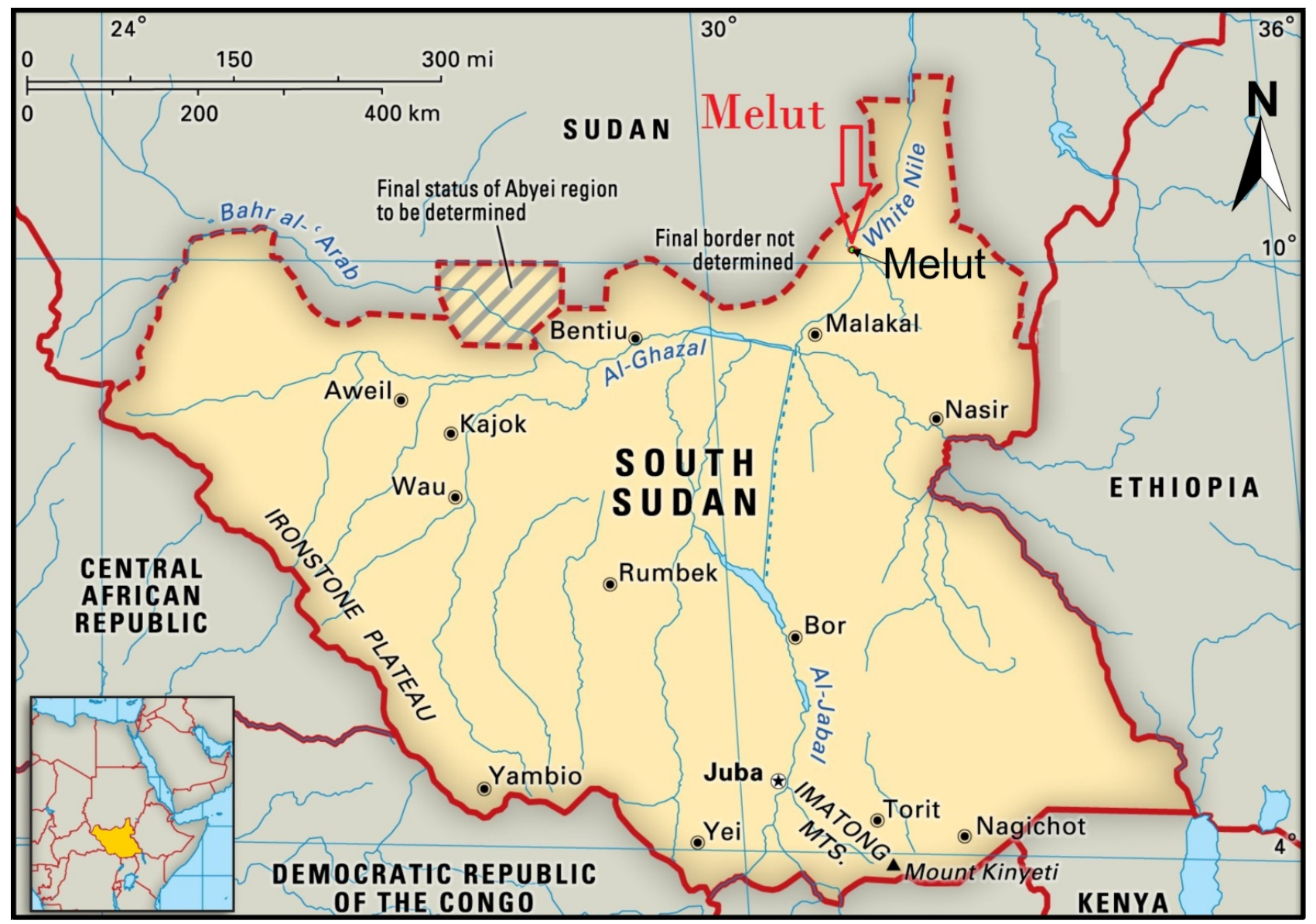

Figure 1. Location map of Study area.

and rocks. Estimating the accuracy of land cover classifications was performed by comparing a classified land-use to a reference map based on Google earth imageries.

\subsection{Phytoremediation Setup}

The sampled macrophytes were washed thoroughly 3 times using tap water, 2 times using distilled water and kept on a filter paper to remove excess water present in the macrophytes. Lemna minor L., Azolla pinnata and a combination of Lemna minor and Azolla pinnata were then transferred into different trough having capacity of 30 liter containing oil polluted water, the control contains only oil polluted water with neither Lemna minor nor Azolla pinnata. The physico-chemical parameter of the oil polluted water (turbidity, electrical conductivity (EC), nitrate, total dissolved solid (TDS), total suspended solid (TSS), chemical oxygen demand (COD), biological oxygen demand (BOD), phosphate, chlorides and hardness) was determined using standard method according to APHA [33]. After 28 days the macrophytes were removed the test macrophytes were removed from the trough and the physico-chemical parameter of the treated water was re-determine according to the previous method employed. Lemna minor and Azolla pinnata from each of the set-up were removed and separated into leaves, stem and root then oven dried. The dried material was then 
grounded and subjected to acid digestion using $\mathrm{HNO}_{3}$ and $\mathrm{HClO}_{4}$. The digested samples were then analyzed for the determination of the concentration of lead $(\mathrm{Pb})$ and cadmium $(\mathrm{Cd})$ in the test macrophytes. The determination of heavy metal concentration was done using Atomic Absorption Spectrophotometer (AAS). The reduction efficiency, bioconcentration factor and biotranslocation factor was thus determined using the formula below:

$$
\begin{gathered}
\text { Reduction Efficiency }=\frac{Z-Y}{Z} \times \frac{100}{1} \\
\text { Bioconcentration Factor }=\frac{P}{T} \\
\text { Biotranslocation Factor }=\frac{E}{P}
\end{gathered}
$$

where $Z=$ Initial concentration, $Y=$ Final concentration, $P=$ metal concentration in root, $T=$ metal concentration in wastewater, and $E=$ metal concentration in shoot.

\subsection{Biosorption Setup}

Lemna minor L. and Azolla pinnata were cut into small pieces and washed 3 times using borehole water and twice using distilled water. The macrophytes were then dried in sunlight for 24 hours. The dry macrophytes were ground using a mechanical blender and sieved using a standard sieve to obtain two sizes of each macrophyte $(30 \mathrm{~mm}$ and $60 \mathrm{~mm}$ ). The process materials are stored separately in an airtight container until needed during use. The efficiency of these macrophytes in the biosorption of $\mathrm{Pb}^{2+}$ and $\mathrm{Cd}^{2+}$ from oil polluted water was tested under conditions such as particle size, contact time and dosage of the particle. The effect of particle size and contact time on the absorption of $\mathrm{Pb}^{2+}$ and $\mathrm{Cd}^{2+}$ from oil polluted water was determined by placing $2 \mathrm{~g}$ each of Lemna minor L., Azolla pinnata and the combination of Lemna minor L. and Azolla pinnata in equal proportion separately in a $250 \mathrm{ml}$ conical flask containing the polluted water. The processed materials are of two particle sizes of $30 \mathrm{~mm}$ and 60 $\mathrm{mm}$. The mixture was then shaken at $150 \mathrm{rmp}$ using a magnetic shaker for different time intervals of 30,50,70, 90, and 120 minutes. The mixture was then filtered and $\mathrm{Pb}^{2+}$ and $\mathrm{Cd}^{2+}$ were determined using AAS techniques. The effect of absorbent dosage was determined by placing $1 \mathrm{~g}, 2 \mathrm{~g}, 3 \mathrm{~g}, 4 \mathrm{~g}$, and $5 \mathrm{~g}$ each of Lemna minor L., Azolla pinnata, and the combination of Lemna minor L. and Azolla pinnata in equal proportions separately in a $250 \mathrm{ml}$ conical flask containing the polluted water. The processed materials are of two particle sizes of 30 $\mathrm{mm}$ and $60 \mathrm{~mm}$. The mixture was then shaken at $150 \mathrm{rmp}$ using a magnetic shaker for 1 hour. The mixture was then filtered and $\mathrm{Pb}^{2+}$ and $\mathrm{Cd}^{2+}$ were determined using AAS techniques. The biosorption efficiency was thus determined using the formula below:

$$
\text { Biosorption Efficiency }=\frac{C_{k}-C_{l}}{C_{k}}
$$


where $C_{k}$ and $C_{l}$ are initial and final concentration of $\mathrm{Pb}^{2+}$ and $\mathrm{Cd}^{2+}$ in the sample before and after shaking [34].

\subsection{Effect of Absorbent Dosage}

The effect of adsorbent dosage was studied by placing $1 \mathrm{~g}, 2 \mathrm{~g}, 3 \mathrm{~g}, 4 \mathrm{~g}$, and $5 \mathrm{~g}$ each of Azolla Pinnata Lemna minor $\mathrm{L}$ and combination of Azolla pinnata and Lemna minor $\mathrm{L}$ where placed in to a solution $250 \mathrm{ml}$ of solution containing 4.5 $\mathrm{mg} / \mathrm{l}$ of $\mathrm{Pb}^{2+}$ and $\mathrm{Cd}^{2+}$ and shaken at $150 \mathrm{rpm}$ using a magnetic stirrer for $1 \mathrm{~h}$ at a constant temperature of $25^{\circ} \mathrm{C}$. The samples were filtered and the $\mathrm{Pb}^{2+}$ and $\mathrm{Cd}^{2+}$ concentrations of the solution were determined using AAS technique. $\mathrm{Pb}^{2+}$ and $\mathrm{Cd}^{2+}$ Percentage removal was calculated using Equation (2) [29].

\subsection{Adsorption Equilibrium Study}

Adsorption equilibrium study for $\mathrm{Ni}^{2+}$ using Azolla Pinnata Lemna minor $\mathrm{L}$ and combination of Azolla pinnata and Lemna minor $\mathrm{L}$ was performed by placing 1 g, 2 g, 3 g, 4 g, and 5 g of Azolla Pinnata Lemna minor L and combination of Azolla pinnata and Lemna minor $\mathrm{L}$ in a solution of $5 \mathrm{mg} / \mathrm{l}, 10 \mathrm{mg} / \mathrm{l}, 15 \mathrm{mg} / \mathrm{l}, 20$ $\mathrm{mg} / \mathrm{l}$ and $25 \mathrm{mg} / \mathrm{l}$ of $\mathrm{Pb}^{2+}$ and $\mathrm{Cd}^{2+}$ and shake at using a magnetic stirrer at 150 rpm for $24 \mathrm{~h}$ at a constant temperature of $25^{\circ} \mathrm{C}$. The samples were filtered and the $\mathrm{Pb}^{2+}$ and $\mathrm{Cd}^{2+}$ concentrations of the solution were determined using AAS technique. Langmuir and Freundlich isotherm models were thus determined using Equations (3) and (5) [35].

Langmuir equation is represented below:

$$
\frac{1}{q_{x}}=\frac{1}{b_{i} q_{f}} \cdot T_{e}+\frac{1}{q_{f}}
$$

The equation above was adopted from Kumar et al. [29], where $T_{e}$ is equilibrium $\mathrm{Pb}^{2+}$ and $\mathrm{Cd}^{2+}$ concentration in solution, $q_{f}$ is maximum $\mathrm{Pb}^{2+}$ and $\mathrm{Cd}^{2+}$ absorbed per unit weight of Azolla Pinnata Lemna minor L and combination of Azolla pinnata and Lemna minor $\mathrm{L}, b_{i}$ is affinity adsorbate. The value of $q_{f}$ and $b_{i}$ is determined from the slope and intercept. $Z_{l}$ is the separation factor and is calculated using the formula below:

$$
Z_{l}=\frac{1}{1+b_{i} T_{g}}
$$

where $T_{g}$ is the initial concentration of $\mathrm{Pb}^{2+}$ and $\mathrm{Cd}^{2+}$ in the solution.

Freundlich Isotherm is represented below:

$$
\log \left(q_{x}\right)=\log \left(K_{f}\right)+\frac{1}{r \log T_{e}}
$$

The equation was adopted from Wang et al. [36], where $K_{f}$ is Freundlich constant $r$ is Freundlich coefficient, and $K_{f}$ and $r$ are determined by plotting a graph of $q_{x}$ against $T$ [36].

\subsection{Adsorption Kinetics}

Adsorption kinetics is fundamental in describing the character of an absorbent. 
To ascertain the mechanism involved in the adsorption of $\mathrm{Pb}^{2+}$ and $\mathrm{Cd}^{2+}$ by Azolla Pinnata Lemna minor $\mathrm{L}$ and combination of Azolla pinnata and Lemna minor L. Pseudo first-order and the pseudo second-order reaction was used [37].

The pseudo first-order is represented below:

$$
\log \left(q_{i}-q_{t}\right)=\log \left(q_{i}\right)-\frac{K_{i} T}{2.303}
$$

The pseudo second order is represented below:

$$
\frac{T}{q_{t}}=\frac{1}{K_{2} q_{2}}+\frac{T}{q_{2}}
$$

\subsection{Statistical Analysis}

The experimental procedure was triplicate and data obtained was presented as mean \pm deviation as represented using error bar in chart. The mean reduction efficiency of Lemna minor L., Azolla pinnata and the combination of Lemna minor L. and Azolla pinnata was compared with the mean reduction obtained from the control using one-way analysis of variance at $5 \%$ significant differences.

\section{Result and Discussion}

\subsection{Landuse and Landcover Change}

Table 1 indicates the changes in land-use that occurred in the area of study for a given period (2000-2020). Built up areas have increased by 8 percent between the periods. The reason behind the increase could be as a result of an increase in the population. As the population increases, the need for housing/shelter also increases. The water body increased by 2 percent. The activities of the people in the area could be the reason for the increase (Figure 2). The present of mining ditches that are created by people during mining activities can help in holding water after rainfall. For that reason, the percentage of water coverage increased in the area. The increment for the sparse vegetation is also significantly high. For the period of the study, it increased by 7 percent. Agricultural land is also part of

Table 1. Area coverage of each land-use classes and change detection between 2000 and 2020.

\begin{tabular}{ccccccc}
\hline \multirow{2}{*}{ NAME } & \multicolumn{2}{c}{ LULC 2000 } & \multicolumn{2}{c}{ LULC 2020 } & \multicolumn{2}{c}{ 2000-2020 } \\
\cline { 2 - 7 } & Area $\left(\mathbf{k m}^{2}\right)$ & $\%$ & Area $\left(\mathbf{k m}^{2}\right)$ & $\%$ & Area $\left(\mathbf{k m}^{2}\right)$ & $\%$ \\
\hline BUILT UP AREA & 114 & 3 & 374 & 11 & 260 & 8 \\
WATER BODY & 39 & 1 & 113 & 3 & 74 & 2 \\
SPARSE VEGETATION & 789 & 23 & 1037 & 30 & 248 & 7 \\
DENSE VEGETATION & 1300 & 38 & 1511 & 44 & 211 & 6 \\
BARE SURFACE & 847 & 25 & 259 & 8 & -587 & -17 \\
ROCK & 358 & 10 & 152 & 4 & -206 & -6 \\
TOTAL & 3446 & 100 & 3446 & 100 & & \\
\hline
\end{tabular}




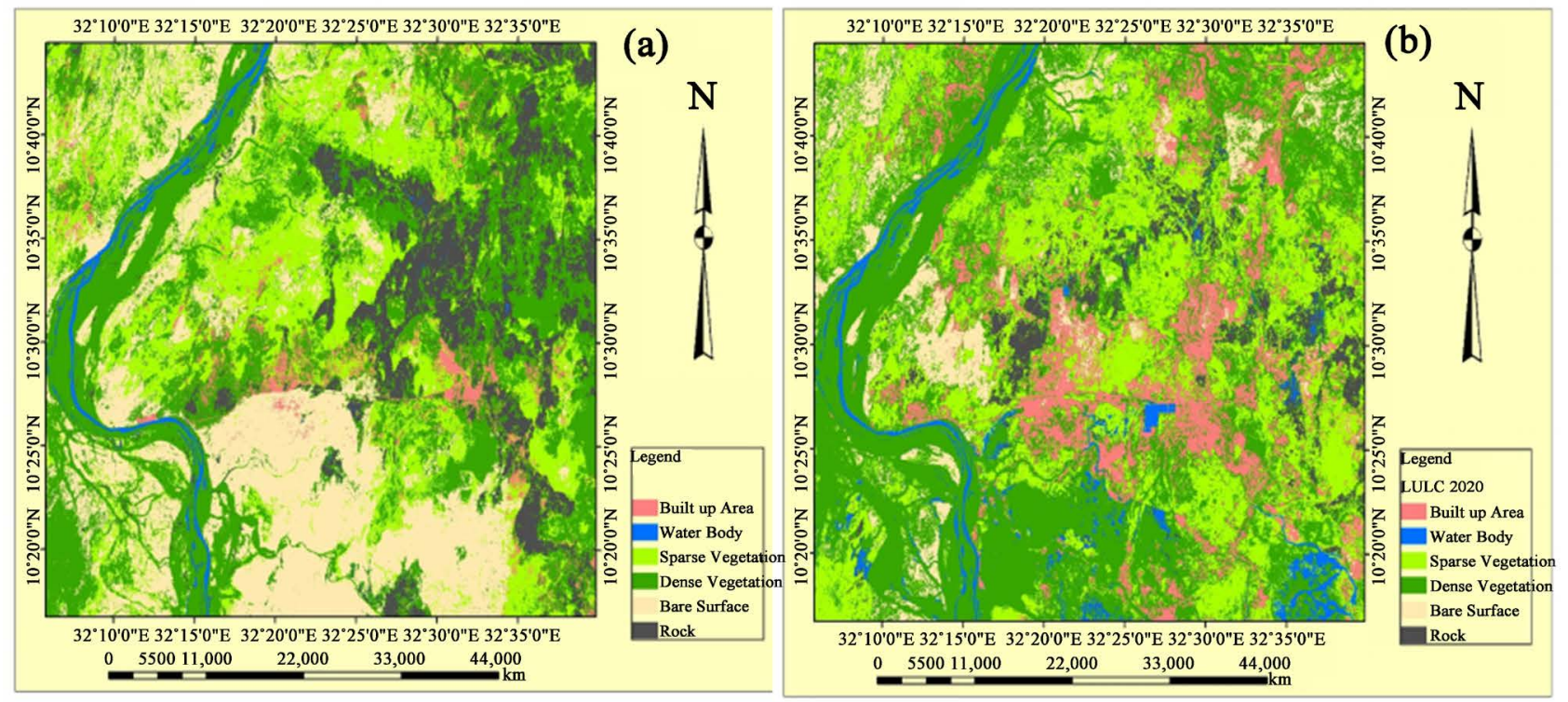

Figure 2. Classified land use land cover of Paloich and neighbouring environs (a) 2000 and (b) 2020.

this sparse vegetation; the increase could be as a result of the increase in agricultural activities by people. Dense vegetation increased by 6 percent. But relating it to the study area, the area is affected by different kinds of conflict which displaces a lot of people from their homes. Many of these areas are empty, which gives the plant the ability to regenerate. The increase in other land-uses, like vegetation, and built-up areas, affect the coverage of bare surface. Since this bare surface is just open land, it gives other land-uses the ability to cover part of this open space. The percentage of rock in the area also significantly dropped to about-6 percent. This decrease could likely be as a result of mining activities in the area. As it is all known, these rocks are formed from the aggregate of different minerals. This gives them the ability to store precious materials like gold, silver, and other precious materials. People break rocks because of this mineral deposit.

\subsection{Phytoremediation}

The result obtained shows significant differences between turbidity, EC, TDS, TSS, COD, BOD, nitrate, phosphate, chloride and hardness of the petroleum-contaminated water containing Lemna minor L. alone, Azolla pinnata alone and combination of Lemna minor and Azolla pinnata if compared with the contaminated water containing neither Lemna minor nor Azolla pinnata (control). Although, higher pollutant reduction efficiency was recorded in the trough containing a mixture of both Lemna minor L. and Azolla pinnata (Figure 3). The result obtained also shows high $\mathrm{Cd}^{2+}$ and $\mathrm{Pb}^{2+}$ reduction efficiency from the wastewater with Azolla pinnata having $83 \%$ and $87 \%$ reduction efficiency of $\mathrm{Cd}^{2+}$ and $\mathrm{Pb}^{2+}$ respectively, Lemna minor $\mathrm{L}$ having $91 \%$ and $85 \%$ reduction efficiency for $\mathrm{Cd}^{2+}$ and $\mathrm{Pb}^{2+}$ respectively while the combination of both plants in a trough shows high pollutant reduction efficiency of $95 \%$ and $97 \%$ of $\mathrm{Cd}^{2+}$ and 

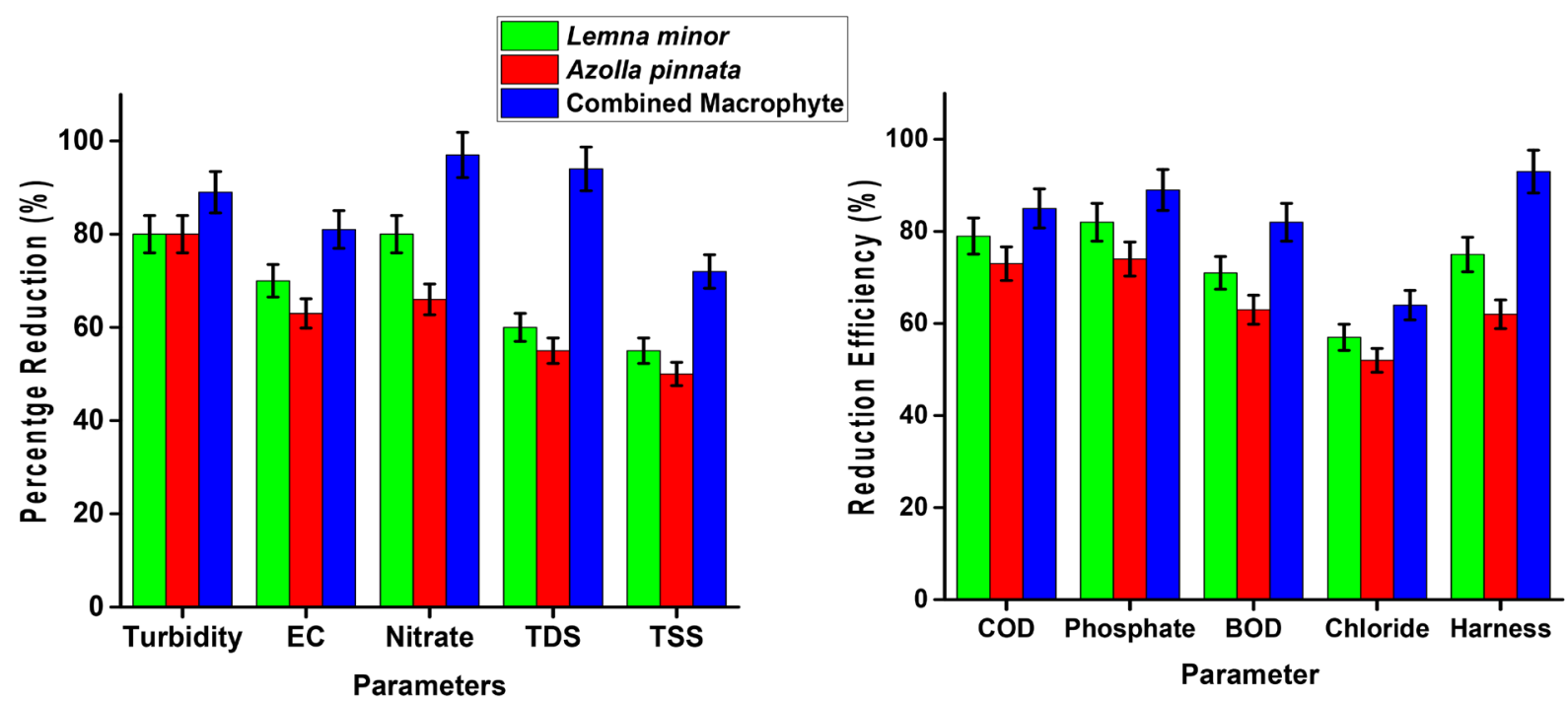

Figure 3. Phytoremediation efficiency of the test plants.

$\mathrm{Pb}^{2+}$ respectively. The result obtained shows high bio concentration factor and bio translocation factor of $\mathrm{Cd}^{2+}$ and $\mathrm{Pb}^{2+}$ of above 1 for the entire test macrophytes category. The reduction in TDS and TSS is responsible for the high EC and turbidity reduction due to the direct correlation between both parameters. This high TDS and TSS reduction efficiency by the entire test macrophytes categories could be attributed to the ability of the root of the macrophytes to retain minute suspended solids or the ability of the test macrophytes to stimulate the growth of microbes which in turn brings about the decomposition of these particles [38]. The high nitrate, phosphate and chloride reduction by the macrophytes could be attributed to the fact that the plants were able to utilize these substances as nutrients for growth and development. Continuous exposure of the plant to the wastewater water would lead to the continuous removal of nitrate and phosphate until 100\% efficiency is attain whereas, prolong exposure of the test plants to the wastewater might not necessarily favor continuous chloride removal because chloride is need by the plants in minute quantity [39]. The high BOD and COD reduction efficiency by Azolla pinnata, Lemna minor L. and combination of Lemna minor and Azolla pinnata is attributed to the fact that that the test plants stimulate the growth of microorganism which brings about the degradation of organic compounds present in the wastewater [40] [41]. The high biotranslocation factor, bioconcentration factor and reduction efficiency is attributed to the low $\mathrm{Cd}^{2+}$ and $\mathrm{Pb}^{2+}$ of $0.09 \mu \mathrm{g} / \mathrm{l}$ and $0.01 \mu \mathrm{g} / \mathrm{l}$ present in the wastewater. This heavy metal concentration is below the maximum concentration of $10 \mu \mathrm{g} / \mathrm{l}-15 \mu \mathrm{g} / \mathrm{l}$ reported by most researchers.

\subsection{Biosorption}

The result obtained shows that for Lemna minor L. Azolla pinnata and Combined material maximum absorption efficiency was obtained at a higher dosage for both $\mathrm{Pb}$ and $\mathrm{Cd}$. This result signifies that increasing dosage of the test ma- 
crophytes leads to the increasing availability of the more binding site to bind available $\mathrm{Pb}$ and $\mathrm{Cd}$. This result shows that higher biomass of Lemna minor $\mathrm{L}$. Azolla pinnata and Combined material have a higher tendency of removing $\mathrm{Pb}$ and Cd than lower biomass of Lemna minor L. Azolla pinnata and Combined material. The result obtained in Figure 4 and Figure 5 shows that the absorption of $\mathrm{Pb}$ and $\mathrm{Cd}$ by Lemna minor $\mathrm{L}$. increases with increasing contact time for both larger and smaller material while for Azolla pinnata the absorption of $\mathrm{Pb}$ and $\mathrm{Cd}$ increases with increasing contact time until $100 \mathrm{~min}$, beyond 100 minute the absorption of $\mathrm{Pb}$ and $\mathrm{Cd}$ by Azolla pinnata decreases with increasing contact time. The absorption efficiency of the combined material tends to increase with increasing contact time but maintain a uniform absorption rate for $\mathrm{Pb}$ and $\mathrm{Cd}$ beyond 100 minutes. A comparison of the absorption efficiency of $\mathrm{Pb}^{2+}$ by larger and smaller sized particles shows that the larger size material and smaller size materials shows higher absorption efficiency by larger sized particle of Azolla pinnata than lower sized particle before shaking time of 100 minutes after which smaller sized particle have higher absorption efficiency. The result also shows that a higher absorption efficiency was obtained using small sized Lemna minor
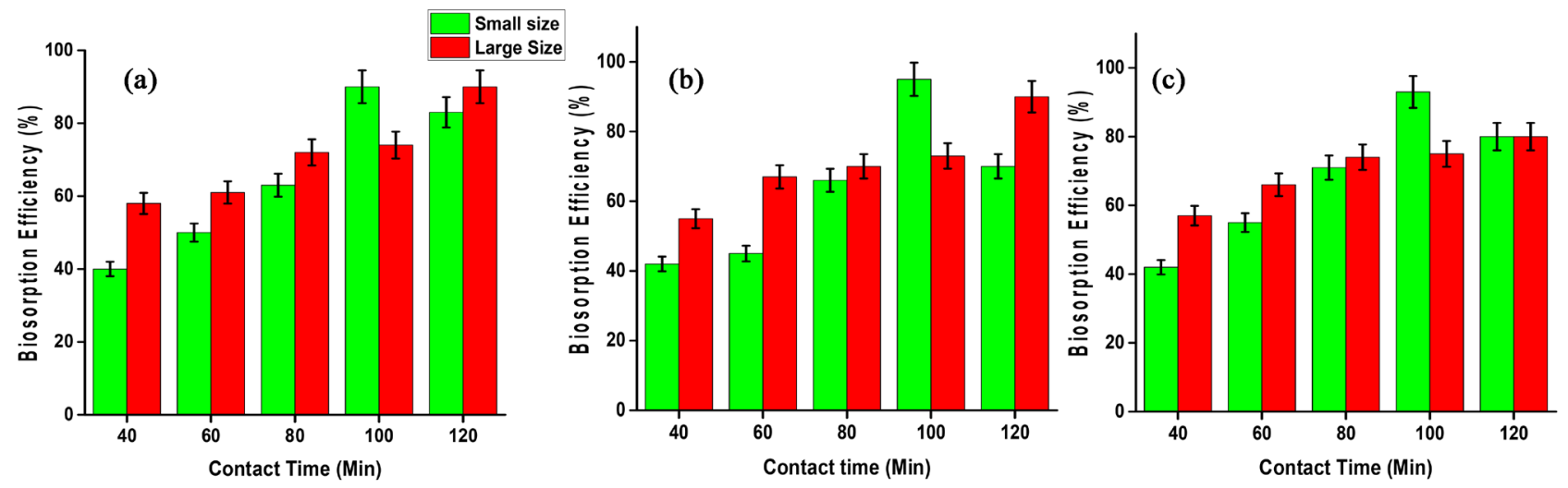

Figure 4. Biosorption Efficiency of Cd by the Test Plants (a) Lemna minor L. (b) Azolla pinnata (c) Combined material.
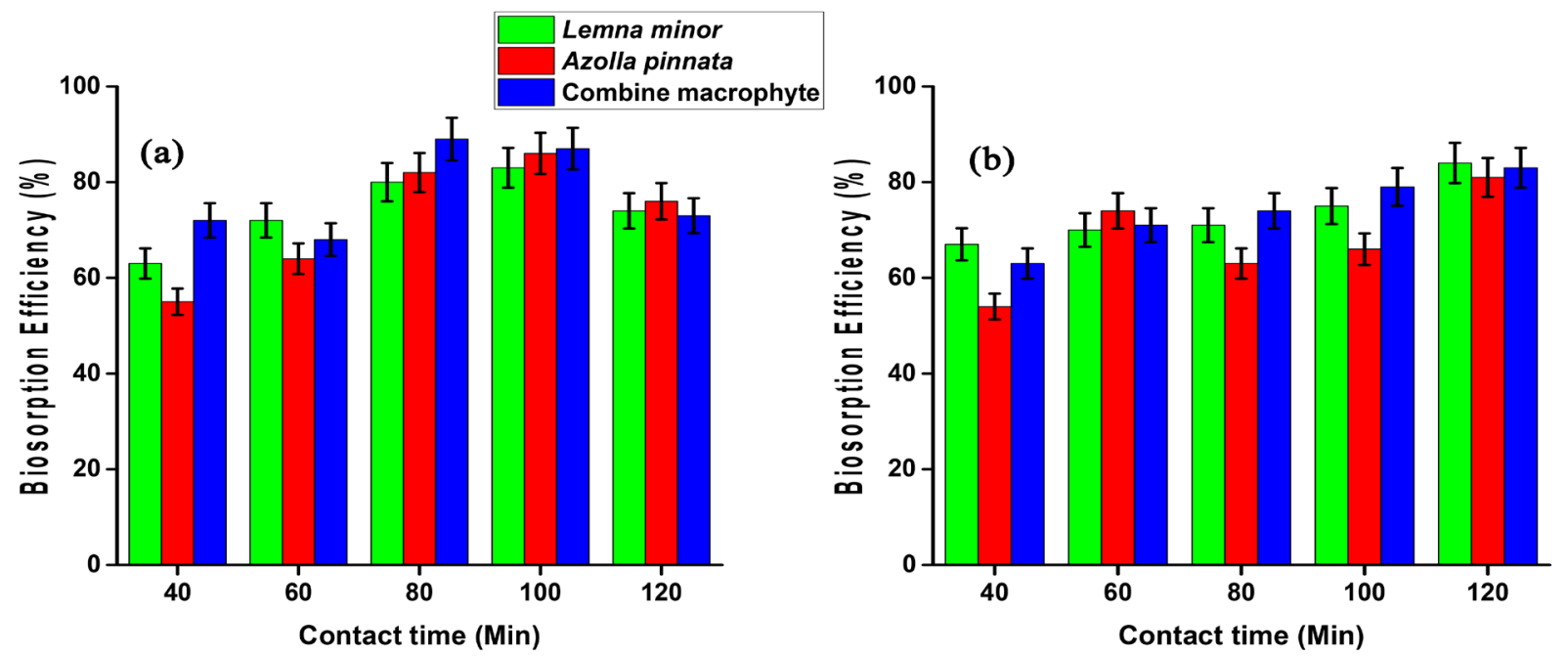

Figure 5. Biosorption Efficiency of Pb by the Test Plants (a) Small Size (b) Large size. 
L. if compare to larger sized particles except at shaking time of 50 minutes and beyond 100 minutes. Combined material shows higher absorption efficiency for larger sized particles until shaking time of 70 minutes. Beyond shaking time of 70 minutes higher absorption efficiency was obtained for smaller sized particles. The result display in Figure 6 shows the increasing biosorption efficiency of $\mathrm{Pb}$ and $\mathrm{Cd}$ with increasing absorbent dosage and this is as a result of the increasing functional group resulting from the increase in the mass of the absorbent [29].

\subsection{Adsorption Isotherms}

The Langmuir model obtained gives a nearly perfect fitting for adsorption of $\mathrm{Pb}$ and Cd for Lemna minor (0.9997 and 0.9967) and Azolla pinnata (0.9995 and $0.9974)$ and the combined material (0.9994 and 0.9938). Although it can be concluded that the adsorption of $\mathrm{Pb}$ and $\mathrm{Cd}$ onto Lemna minor and Azolla pinnata correlated well with Langmuir equation with the relationship becoming more linear with $\mathrm{R}^{2}$ value closer to 1 [42]. The Freundlich model also shows a nearly perfect fitting for absorption of $\mathrm{Pb}$ and $\mathrm{Cd}$ for Lemna minor (0.9998 and 0.9971), Azolla pinnata (0.9995 and 0.9953) and combined material (0.9965 and 0.9972) with a high n value of (2.5) Lemna minor, (2.9) Azolla pinnata and (2.1) combined material which are all within the range of 1 - 10 signifying favorable absorption of $\mathrm{Pb}$ and $\mathrm{Cd}[43]$ [44].

\subsection{Adsorption Kinetics}

The biosorption of $\mathrm{Pb}$ and $\mathrm{Cd}$ by Lemna minor, Azolla Pinnata and combined material was determined at various initial concentration and time interval for the understanding of biosorption mechanism [35]. The result obtained shows that the Pseudo Second-order kinetic model gives nearly perfect fitting for Lemna minor (0.9194) and Azolla pinnata (0.9645) and combined material (0.7329).

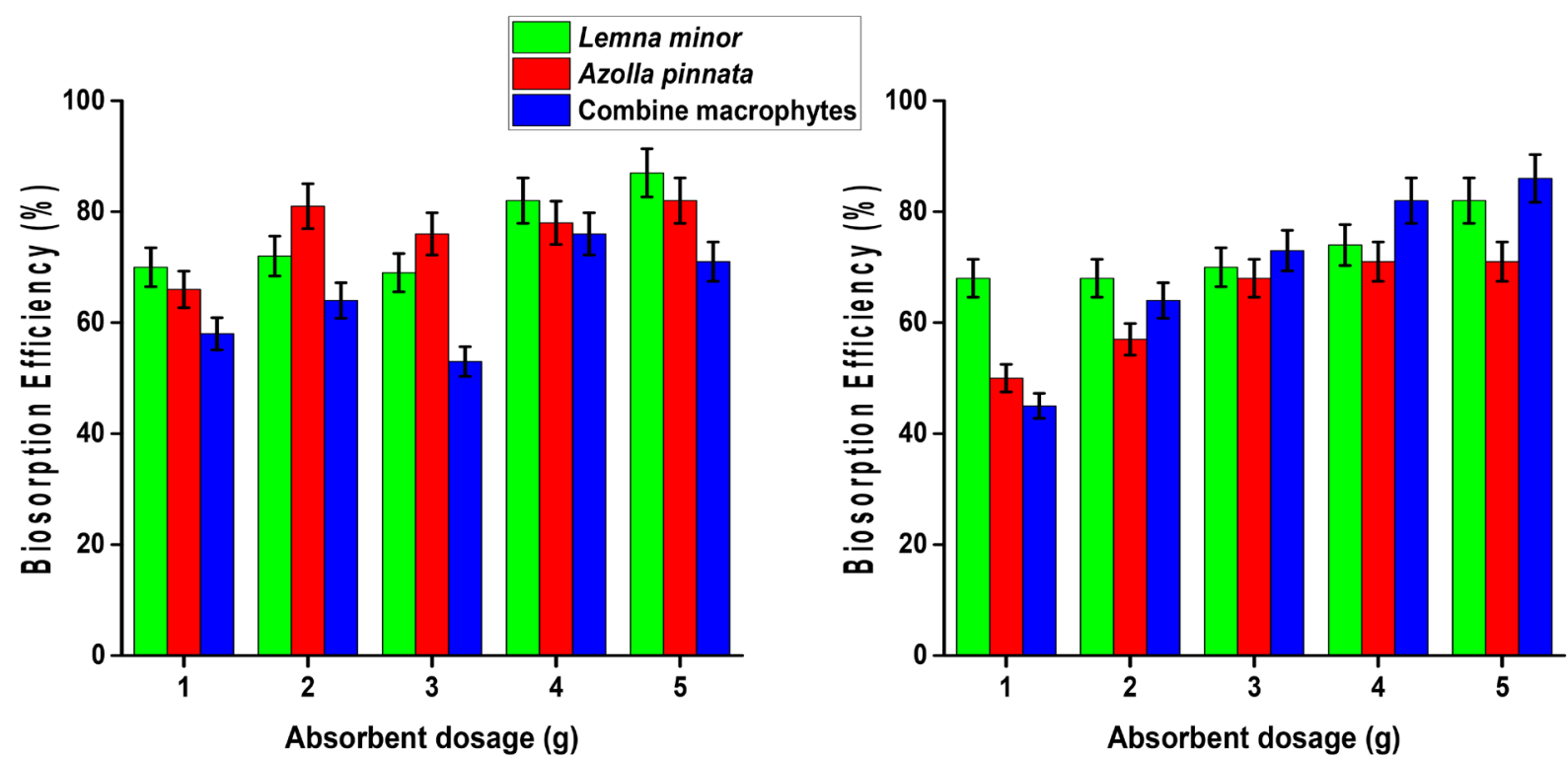

Figure 6. Effect of Absorbent Dosage on the Biosorptin of the test plants to (a) $\mathrm{Pb}(\mathrm{b}) \mathrm{Cd}$. 
The correlation coefficient shows that the absorption of $\mathrm{Pb}$ and $\mathrm{Cd}$ by these macrophytes follows the pseudo second-order kinetic model because poor fittings of (0.7501) Lemna minor, (0.5678) Azolla pinnata and (0.5404) combine material was obtained for pseudo-first order model. This result obtained signifies that that the absorption of $\mathrm{Pb}$ and $\mathrm{Cd}$ to the macrophytes is due to the chemical and physical reaction of $\mathrm{Pb}$ and $\mathrm{Cd}$ and the surface of the macrophytes which leads to the formation of the bond between the valence electron and the negative surface charge of the macrophytes to attain an equilibrium state [45].

\section{Conclusion}

The petrochemical industry is the world's largest contributor of $\mathrm{Pb}$ and $\mathrm{Cd}$ particularly in developing countries like South Sudan where water contaminated with $\mathrm{Pb}$ and $\mathrm{Cd}$ is discharged into nearby water bodies without proper treatment due to low technologic know-how and lack of information. It is thereby paramount for petrochemical industries to utilize the availability of aquatic macrophytes as low-cost absorbents for further treatment of its wastewater before discharge since most industries are unwilling to establish a costly convectional treatment plant. Further investigation is needed on how to increase the efficiency of these macrophytes for the uptake of $\mathrm{Pb}$ and $\mathrm{Cd}$. More research needs to be done using more macrophytes such as Salvinia $s p$ and Ludwigia $s p$, etc. to discover more novel eco-friendly cheap biosorbent for $\mathrm{Pb}$ and $\mathrm{Cd}$ removal from petrochemical polluted water.

\section{Conflicts of Interest}

The authors declare no conflicts of interest regarding the publication of this paper.

\section{References}

[1] Fenske, J. and Zurimendi, I. (2017) Oil and Ethnic Inequality in Nigeria. Journal of Economic Growth, 22, 397-420. https://doi.org/10.1007/s10887-017-9149-8

[2] Rawlings, A.V. and Lombard, K.J. (2012) A Review on the Extensive Skin Benefits of Mineral Oil. International Journal of Cosmetic Science, 34, 511-518. https://doi.org/10.1111/j.1468-2494.2012.00752.x

[3] Ugya, A.Y. (2015) The Efficiency of Lemna minor L. in the Phytoremediation of Romi Stream: A Case Study of Kaduna Refinery and Petrochemical Company Polluted Stream. Journal of Applied Biology and Biotechnology, 3, 11-14.

[4] Sall, M.L., Diaw, A.K.D., Gningue-Sall, D., Efremova Aaron, S. and Aaron, J.-J. (2020) Toxic Heavy Metals: Impact on the Environment and Human Health, and Treatment with Conducting Organic Polymers, A Review. Environmental Science and Pollution Research, 27, 29927-29942. https://doi.org/10.1007/s11356-020-09354-3

[5] Nkwunonwo, U.C., Odika, P.O. and Onyia, N.I. (2020) A Review of the Health Implications of Heavy Metals in Food Chain in Nigeria. The Scientific World Journal, 2020, Article ID: 6594109. https://doi.org/10.1155/2020/6594109

[6] Kuch, S. and Bavumiragira, J.P. (2019) Impacts of Crude Oil Exploration and Pro- 
duction on Environment and Its Implications on Human Health: South Sudan Review. International Journal of Scientific and Research Publications (IJSRP), 9, 247-256. https://doi.org/10.29322/IJSRP.9.04.2019.p8836

[7] Harris, R.C. (1971) Ecological Implication of Mercury Pollution in Aquatic Systems. Biological Conservation, 3, 279-283. https://doi.org/10.1016/0006-3207(71)90338-7

[8] Spallholz, J.E. and Hoffman, D.J. (2002) Selenium Toxicity: Cause and Effects in Aquatic Birds. Aquatic Toxicology, 57, 27-37. https://doi.org/10.1016/S0166-445X(01)00268-5

[9] Ugya, Y.A., Hasan, D.B., Tahir, S.M., Imam, T.S., Ari, H.A. and Hua, X. (2021) Microalgae Biofilm Cultured in Nutrient-Rich Water as a Tool for the Phycoremediation of Petroleum-Contaminated Water. International Journal of Phytoremediation, 23, 1175-1183. https://doi.org/10.1080/15226514.2021.1882934

[10] Vandermeulen, J.H. and Ross, C.W. (1995) Oil Spill Response in Freshwater: Assessment of the Impact of Cleanup as a Management Tool. Journal of Environmental Management, 44, 297-308. https://doi.org/10.1016/S0301-4797(95)90338-0

[11] Burcharth, H.F., Hawkins, S.J., Zanuttigh, B. and Lamberti, A. (2007) Chapter 14: Background Knowledge and Tools for Prediction of Ecological Impacts. In: Burcharth, H.F., Hawkins, S.J., Zanuttigh, B. and Lamberti, A., Eds., Environmental Design Guidelines for Low Crested Coastal Structures, Elsevier Science Ltd., Oxford, 335-345. https://doi.org/10.1016/B978-008044951-7/50034-8

[12] Ugya, A.Y., Hua, X. and Ma, J. (2019) Phytoremediation as a Tool for the Remediation of Wastewater Resulting from Dyeing Activities. Applied Ecology and Environmental Research, 17, 3723-3735. https://doi.org/10.15666/aeer/1702 37233735

[13] Boening, D.W. (2000) Ecological Effects, Transport, and Fate of Mercury: A General Review. Chemosphere, 40, 1335-1351. https://doi.org/10.1016/S0045-6535(99)00283-0

[14] Khatun, R., Reza, M.I.H., Moniruzzaman, M. and Yaakob, Z. (2017) Sustainable Oil Palm Industry: The Possibilities. Renewable and Sustainable Energy Reviews, 76, 608-619. https://doi.org/10.1016/j.rser.2017.03.077

[15] Eze, S.I., Akpomie, K.G., Ezeofor, C.C., Mmadubuike, N.V. and Ojo, F.K. (2019) Remediation of Oil Spill Polluted Water from Niger Delta Nigeria by Sorption onto Ammonium Sulfate Modified Dialium guineense Seed Husk. Petroleum Science and Technology, 37, 1830-1838. https://doi.org/10.1080/10916466.2019.1608240

[16] Hayat, S., Ahmad, I., Azam, Z.M., Ahmad, A., Inam, A. and Samiullah (2002) Effect of Long-Term Application of Oil Refinery Wastewater on Soil Health with Special Reference to Microbiological Characteristics. Bioresource Technology, 84, 159-163. https://doi.org/10.1016/S0960-8524(02)00027-5

[17] Amare, E., Kebede, F., Berihu, T. and Mulat, W. (2018) Field-Based Investigation on Phytoremediation Potentials of Lemna minor and Azolla filiculoides in Tropical, Semiarid Regions: Case of Ethiopia. International Journal of Phytoremediation, 20, 965-972. https://doi.org/10.1080/15226514.2017.1365333

[18] Ding, J., Yang, W., Wang, S., Zhang, H., Yang, Y., Bao, X. and Zhang, Y. (2020) Effects of Environmental Metal Pollution on Reproduction of a Free-Living Resident Songbird, the Tree Sparrow (Passer montanus). Science of the Total Environment, 721, Article ID: 137674. https://doi.org/10.1016/j.scitotenv.2020.137674

[19] Ugya, A.Y., Hua, X., Agamuthu, P. and Ma, J. (2019) Molecular Approach to Uncover the Function of Bacteria in Petrochemical Refining Wastewater: A Mini Review. Applied Ecology and Environmental Research, 17, 3645-3665.

https://doi.org/10.1016/j.ecoenv.2014.03.029 
[20] Wang, X., Qu, R., Wei, Z., Yang, X. and Wang, Z. (2014) Effect of Water Quality on Mercury Toxicity to Photobacterium phosphoreum: Model Development and Its Application in Natural Waters. Ecotoxicology and Environmental Safety, 104, 231-238. https://doi.org/10.1016/j.ecoenv.2014.03.029

[21] Tuomi, T., Veijalainen, H. and Santonen, T. (2018) Managing Exposure to Benzene and Total Petroleum Hydrocarbons at Two Oil Refineries 1977-2014. International Journal of Environmental Research and Public Health, 15, Article No. 197. https://doi.org/10.3390/ijerph15020197

[22] Yilmaz, A., Yanar, A. and Alkan, E. (2017) Review of Heavy Metal Accumulation on Aquatic Environment in Northern East Mediterrenean Sea Part I: Some Essential Metals. Reviews on Environmental Health, 32, 119-163. https://doi.org/10.1515/reveh-2016-0065

[23] Chen, C.-C., Tew, K.S., Ho, P.-H., Ko, F.-C., Hsieh, H.-Y. and Meng, P.-J. (2017) The Impact of Two Oil Spill Events on the Water Quality along Coastal Area of Kenting National Park, Southern Taiwan. Marine Pollution Bulletin, 124, 974-983. https://doi.org/10.1016/j.marpolbul.2017.02.034

[24] Ugya, A. Y., Hua, X. and Ma, J. (2019) Biosorption of $\mathrm{Cr}^{3+}$ and $\mathrm{Pb}^{2+}$ from Tannery Wastewater Using Combined Fruit Waste. Applied Ecology and Environmental Research, 17, 1773-1787. https://doi.org/10.15666/aeer/1702 17731787

[25] Ezemonye, L.I., Adebayo, P.O., Enuneku, A.A., Tongo, I. and Ogbomida, E. (2019) Potential Health Risk Consequences of Heavy Metal Concentrations in Surface Water, Shrimp (Macrobrachium macrobrachion) and Fish (Brycinus longipinnis) from Benin River, Nigeria. Toxicology Reports, 6, 1-9.

https://doi.org/10.1016/j.toxrep.2018.11.010

[26] Anyanwu, B.O., Ezejiofor, A.N., Igweze, Z.N. and Orisakwe, O.E. (2018) Heavy Metal Mixture Exposure and Effects in Developing Nations: An Update. Toxics, 6, Article No. 65. https://doi.org/10.3390/toxics6040065

[27] Ugya, A.Y., Imam, T.S. and Tahir, S.M. (2015) The Efficiency of Pistia Stratiotes in the Phytoremediation of Romi Stream. International Journal of Health and Research, 5, 492-497.

[28] Ugya, A.Y., Ahmad, A.M., Adamu, I.H., Giwa, S.M. and Imam, T.S. (2019) Phytoextraction of Heavy Metals and Risk Associated with Vegetables Grown from Soil Irrigated with Refinery Wastewater. Journal of Applied Biology and Biotechnology, 7, 14-19. https://doi.org/10.7324/JABB.2019.70203

[29] Kumar, K., Patavardhan, S.S., Lobo, S. and Gonsalves, R. (2018) Equilibrium Study of Dried Orange Peel for Its Efficiency in Removal of Cupric Ions from Water. International Journal of Phytoremediation, 20, 593-598. https://doi.org/10.1080/15226514.2017.1405379

[30] Saha, P., Banerjee, A. and Sarkar, S. (2015) Phytoremediation Potential of Duckweed (Lemna minor L.) on Steel Wastewater. International Journal of Phytoremediation, 17, 589-596. https://doi.org/10.1080/15226514.2014.950410

[31] Central Intelligence Agency (2013) The World Factbook 2013. CIA's 2012 Edition. Central Intelligence Agency, Langley, 864 pages.

[32] United Nations Environment Programme (2007) UNEP 2007 Annual Report. United Nations Environment Programme, Nairobi.

[33] APHA (American Public Health Association), AWWA (American Water Works Association) and WPCF (Water Pollution Control Federation) (1995) Standard Methods for the Examination of Water and Wastewater. American Public Health 
Association, Washington DC.

[34] Ugya, A.Y., Imam, T.S., Hua, X. and Ma, J. (2019) Efficacy of Eicchornia crassipes, Pistia stratiotes and Nymphaea lotus in the Biosorption of Nickel from Refinery Wastewater. Applied Ecology and Environmental Research, 17, 13075-13087. https://doi.org/10.15666/aeer/1706 1307513087

[35] Manikandan, N., Kokeb, A., Goswami, L., Pakshirajan, K. and Pugazhenthi, G. (2016) Waste Litchi Peels for Cr(VI) Removal from Synthetic Wastewater in Batch and Continuous Systems: Sorbent Characterization, Regeneration and Reuse Study. Journal of Environmental Engineering, 142, Article No. C4016001. https://doi.org/10.1061/(ASCE)EE.1943-7870.0001099

[36] Wang, S.-R., Jin, X., Liu, L. and Wu, F. (2010) Use of Low Cost Crop Biological Wastes for the Removal of Nitrobenzene from Water. Desalination, 264, 32-36. https://doi.org/10.1016/j.desal.2010.06.075

[37] Ho, Y.S. and McKay, G. (1998) A Comparison of Chemisorption Kinetic Models Applied to Pollutant Removal on Various Sorbents. Process Safety and Environmental Protection, 76, 332-340. https://doi.org/10.1205/095758298529696

[38] Ugya, A.Y. and Imam, T.S. (2015) The Efficiency of Eicchornia crassipes in the Phytoremediation of Waste Water from Kaduna Refinery and Petrochemical Company. IOSR Journal of Environmental Science, Toxicology and Food Technology, 9, 43-47.

[39] Sood, A., Uniyal, P. L., Prasanna, R. and Ahluwalia, A.S. (2012) Phytoremediation Potential of Aquatic Macrophyte, Azolla. AMBIO, 41, 122-137.

https://doi.org/10.1007/s13280-011-0159-Z

[40] Abou-Shanab, R.A.I., Angle, J.S. and Berkum, P.V. (2007) Chromate-Tolerant Bacteria for Enhanced Metal Uptake by Eichhornia Crassipes (MART.). International Journal of Phytoremediation, 9, 91-105. https://doi.org/10.1080/15226510701232708

[41] Ugya, A.Y., Imam, T.S. and Hassan, A.S. (2015) The Use of Ecchornia crassipes to Remove Some Heavy Metals from Romi Stream: A Case Study of Kaduna Refinery and Petrochemical Company Polluted Stream. IOSR Journal of Pharmacy and Biological Sciences, 10, 43-46.

[42] Amer, M.W., Ahmad, R.A. and Awwad, A.M. (2015) Biosorption of Cu(II), Ni(II), $\mathrm{Zn}(\mathrm{II})$ and $\mathrm{Pb}$ (II) Ions from Aqueous Solution by Sophora Japonica Pods Powder. International Journal of Industrial Chemistry, 6, 67-75. https://doi.org/10.1007/s40090-014-0030-8

[43] Rosales, E., Meijide, I., Tavares, T., Pazos, M. and Sanroman, M.A. (2016) Grapefruit Peelings as a Promising Biosorbent for the Removal of Leather Dyes and Hexavalent Chromium. Process Safety and Environmental Protection, 101, 61-71. https://doi.org/10.1016/j.psep.2016.03.006

[44] Poonam, S., Bharti, K. and Kumar, N. (2018) Kinetic Study of Lead $\left(\mathrm{Pb}^{2+}\right)$ Removal from Battery Manufacturing Wastewater Using Bagasse Biochar as Biosorbent. Applied Water Science, 8, Article No. 119. https://doi.org/10.1007/s13201-018-0765-Z

[45] Low, K.S., Lee, C.K. and Tai, C.H. (1994) Biosorption of Copper by Water Hyacinth Roots. Journal of Environmental Science and Health, Part A: Environmental Science and Engineering and Toxicology, 29, 171-188.

https://doi.org/10.1080/10934529409376028 